\title{
Effects of community-based interventions on physical activity levels: systematic review
}

\section{Efeitos de intervenções comunitárias nos níveis de atividade física: revisão sistemática}

\section{AUTHOR'S \\ Paulo Henrique Guerra ${ }^{1,2}$ (DD \\ Evelyn Helena Corgosinho Ribeiro ${ }^{2}$ (D) \\ Tiago de Lima Rodrigues ${ }^{3}$ (D) \\ Douglas Roque Andrade ${ }^{2,4}$ (D) \\ Mathias Roberto $\operatorname{Loch}^{5}$ (D) \\ 1 Universidade Federal da Fronteira Sul, Chapecó, Santa Catarina, Brasil. \\ 2 Grupo de Estudos e Pesquisas Epidemiológicas em Atividade Física e Saúde da Universidade de São Paulo, São Paulo, Brasil. \\ 3 Programa de Pós-Graduação em Educação \\ Física da Universidade Federal de Santa Catarina, \\ Florianópolis, Santa Catarina, Brasil. \\ 4 Escola de Artes, Ciências e Humanidades da \\ Universidade de São Paulo, São Paulo, Brasil. \\ 5 Programa de Pós-Graduação em Saúde Coletiva da Universidade Estadual de Londrina, Londrina, Paraná, Brasil.}

\section{CORRESPONDING}

Paulo Henrique Guerra

paulo.guerra@uffs.edu.br

Rodovia SC 484, Km 02, Chapecó,

Santa Catarina, Brasil.

CEP: 89815-899.

DOI

$10.12820 /$ rbafs. $25 \mathrm{e} 0130$

\section{(cc) BY}

This work is licensed under a Creative Commons Attribution 4.0 International License.

\begin{abstract}
Aiming to evaluate the effects of community-based interventions on the physical activity (PA) levels in adults, in December, 2017 a systematic review was developed in five electronic databases (Pubmed, Physical Education Index, Scopus, Sportdiscus e Web of Science) and in reference lists, looking for community-based randomised controlled trials (RCT) with interventions aimed at PA increasing levels assessed by objective methods in samples of adults. Risk of bias was assessed using an adapted version of the EPHPP instrument. Of 3,223 articles initially identified, nine composed the descriptive synthesis. Most interventions focused on inactive people and women. In view of the heterogeneity between the PA indicators, a descriptive synthesis of the data was chosen, thus, considering number of steps per day, four of five interventions showed statistically positive results. In regard of moderate-to-vigorous PA levels, two of five interventions showed potential results. Most of interventions were based on educational activities as practices of counselling, home visits and telephone support. Articles with moderate risk of bias were the majority in four of the five domains assessed. In conclusion, most of the studies included showed the potential of community-based interventions to increase the number of steps per day. It is important that future studies discuss operational strategies of interventions, such as counselling and home visits.
\end{abstract}

Keywords: Physical activity; Adult; Public health; Randomized controlled trial; Review.

RESUMO

Com o objetivo de avaliar os efeitos de intervençôes comunitárias nos niveis de atividade física (AF) em adultos, em dezembro de 2017 foi desenvolvida uma revisão sistemática, buscando ensaios controlados randomizados (ECR) comunitários com intervençôes voltadas à promoção da AF avaliadas por métodos objetivos em amostras de adultos. Ao todo, nove ECR compuseram a sintese descritiva. A maioria dos ECR foi direcionada às pessoas inativas e mulheres. Considerando o número de passos por dia, quatro das cinco intervençôes apresentaram resultados estatisticamente positivos. Em relação aos niveis de AF moderadas e vigorosas, duas de cinco intervençôes apresentaram resultados potenciais. A maioria das intervençôes foi baseada em atividades educacionais como práticas de aconselhamento, visitas domiciliares e chamadas telefônicas. Em conclusão, a maioria dos estudos incluidos mostrou o potencial das intervençôes comunitárias ao aumento do número de passos por dia. É importante que futuros estudos debatam estratégias operacionais das intervençôes, como o aconselhamento e visitas domiciliares.

Palavras-chave: Atividade física; Adulto; Saúde pública; Ensaio controlado randomizado; Revisão.

\section{Introduction}

Although physical activity (PA) contributes to the prevention and/or control of a large number of disease ${ }^{1-4}$ and is associated with a reduction in the risk of premature death ${ }^{5}$, approximately $31 \%$ of the world adult population does not reach recommended levels of moderate and vigorous $\mathrm{PA}^{6}$. In view of its global dimension $^{6}$ it is also recognized that $\mathrm{PA}$ is multidetermined by socioeconomic and environmental variables $^{7}$, which raises the importance of studying the particularities of contexts where strategies to promote PA can be implemented.

Apart from the impossibility of better control over contextual variables, in comparison with clinicalbased interventions, previous evidence suggests the potential of community-based strategies for health promotion and prevention of diseases ${ }^{8-10}$. Regarding PA promotion, a previous review ${ }^{11}$ argues about the inconclusiveness of the effects of the community-based interventions, much due to the high methodological 
heterogeneity among the available evidence, which, therefore, justifies the elaboration of a synthesis based on more specifically inclusion criteria, in the sense that its evidence can contribute to the current debate, as well as providing insights for future research.

In this sense, we highlight both the evidence of randomized controlled trials (RCT), due to its better estimate for cause and effect, as well as the use of objective methods for PA assessment (e.g. accelerometers and pedometers), since, when compared with measures based on self-report, suggest more conservative results ${ }^{12,13}$. Thus, the objective of the present study was to evaluate the effects of community-based RCT on the PA levels assessed by objective methods in adults.

\section{Methods}

This review is part of the project "Translation of evidence for decision making in the Brazilian Health System: a review of interventions aiming physical activity promotion", registered in PROSPERO (CRD42015015993). To date, this project aims to raise evidence of community and educational interventions that can be reflected and translated into the Brazilian Health System.

The inclusion criteria of this review were delimited considering the PICOS strategy: Participants: adult populations, without health problems or specific diseases, with the exception of overweight and obesitybased samples. Interventions: with the primary objective of increasing PA levels, which had recruitment and implementation in community settings (e.g. neighbourhoods/districts, primary health care centres and community organizations), with duration of at least six months. Comparators: groups that did not receive any type of intervention or who, according to the authors, received a reduced content of intervention. Outcome: PA levels measured by objective methods. Study design: RCT.

Five electronic databases were used to retrieve the potential studies (Pubmed, Physical Education Index, Scopus, Sportdiscus e Web of Science), covering available literature until 27/12/2017. The systematic searches were developed in accordance to the strategy previously developed for Pubmed: ((((physical activity OR exercise OR physical fitness OR resistance training OR sports OR walk Or walking OR run OR running OR dance OR dancing))) AND ((population OR community OR communities OR communitybased OR primary care OR primary health care $\mathrm{OR}$ basic attention))) AND ((intervention OR treatment OR strategy OR strategies OR program))) AND ((physical activity promotion OR walking promotion OR running promotion OR physical activity level)) Filters: Clinical Trial; Clinical Trial, Phase I; Clinical Trial, Phase II; Clinical Trial, Phase III; Controlled Clinical Trial; Pragmatic Clinical Trial; Randomized Controlled Trial. In addition, manual searches were carried out in the reference lists. A full description of the systematic searches can be requested to the corresponding author.

The search and evaluation of the available evidence were conducted by two experienced researchers (ER and PG), independently, with permanent resolution of disagreements and establishment of consensus.

Data extraction was carried out in an electronic spreadsheet, divided into three domains: (i) descriptive characteristics (e.g. name/acronym of the intervention, location, description of population, age/age group); (ii) methods (e.g. recruitment and implementation site, size of baseline groups and sample losses, description and strategies used in the intervention and control groups, intervention implementation team, instruments and procedures used to assess PA) and (iii) outcomes (e.g. variables analysed, procedures used in of PA data analysis, magnitude and statistical significance of the findings).

Risk of bias was assessed by two independent researchers (PG and TR) with an adapted version ${ }^{14}$ of the Effective Public Health Practice Project (EPHPP $)^{15}$, which covers the following domains of a RCT: selection bias, confounders, blinding of outcome assessor, validity and reproducibility of methods used for PA assessment and losses and withdrawals.

\section{Results}

The flowchart displays the numbers of this review (Figure 1). Briefly, after the identification and removal of 516 duplicates, 2,712 potential articles were evaluated by their titles and abstracts. Of the 182 remaining articles evaluated by their full texts, 173 were excluded, with the main following reasons: interventions (e.g. not community-based or not involving physical activity; $\mathrm{n}$ = 86) and populations (e.g. age range or specific health conditions; $n=37$ ). Thus, nine articles composed the descriptive synthesis ${ }^{16-24}$.

In terms of country, five of the included RCT were developed in the United States of America (55.6\%). In synthesis, mean age ranged from 45 to 77 years $(\text { median }=53)^{19,20}$ and, in relation to the samples, 
women were the majority in all included studies, with four of them with samples only composed by women $(44 \%)^{18-20,24}$. Communities were the most frequent setting in the implementation of interventions $(n=8$; $89 \%)^{16-19,21-24}$. Regarding participants profile, most of the interventions were directed to physically inactive samples $(\mathrm{n}=5)^{16,17,20,21,24}$ (Table 1$)$.

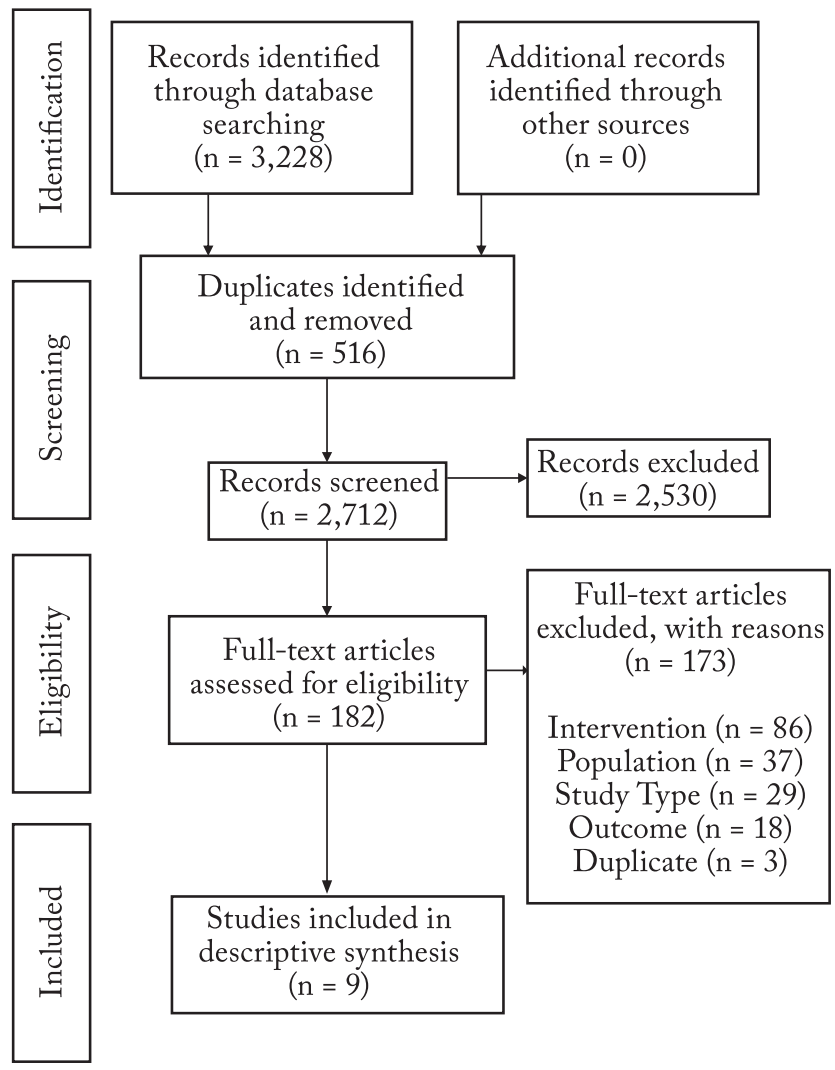

Figure 1 - Flowchart of systematic review
Included samples varied between 30 and 388 participants ${ }^{16,22}$. Regarding duration, the interventions ranged from six to 14 months, with five of them lasting for at least 12 months $(56 \%)^{16-18,23,24}$. Interventions were implemented by health specialists $(n=4)$, Community Health Workers (CHW) $(\mathrm{n}=3)$ and by research teams $(n=2)$. As for the organization of strategies, the most frequent were group meetings $(n=6)^{18-21,23,24}$ and support by telephone calls $(n=6)^{16,18-21,24}$. In five studies, the practice of counselling was developed ( $\mathrm{n}$ $=5)^{17,18,20,21,23}$ (Table 2). One intervention was based exclusively on three-times a week walking sessions, over eight months ${ }^{22}$. For PA assessment, accelerometers were used in six studies ${ }^{16,18-20,23,24}$ and pedometers in two ${ }^{17,22}$. One study used both accelerometers and pedometers ${ }^{21}$ (Table 2).

Figure 2 shows that moderate risk of bias scores were attributed to all studies in the following domains: selection bias (due to samples representing specific populations) and lack of blinding procedure of the outcome assessor. Moderate scores were also attributed more frequently for confounders $(\mathrm{n}=8 ; 88.9 \%)$ and losses and withdrawals $(\mathrm{n}=5 ; 55.6 \%)$. All studies showed low risk of bias for validity and reproducibility of methods used for PA assessment (Figure 2).

In Table 3 , the results of the RCT were grouped into two indicators of $\mathrm{PA}$, aiming at a better presentation of the evidence: (i) number of steps per day, where four (of five) available studies showed significant differences between groups $(80 \%)^{17,19,21,22}$ and (ii) moderate and vigorous PA levels, where two of five studies presented positive after the intervention $(40 \%)^{16,21}$.

Table 1 - Descriptive characteristics of included studies $(n=9)$

\begin{tabular}{|c|c|c|c|c|}
\hline Reference & Country & $\begin{array}{l}\text { Mean age (baseline)/ } \\
\text { Percentage of females }\end{array}$ & $\begin{array}{l}\text { Recruitment/ Implementation } \\
\text { Settings }\end{array}$ & Special characteristics of samples \\
\hline Castro et al. ${ }^{16}$ & USA & $59(66 \%)$ & Community & $\geq 50$ years old physically inactive people \\
\hline Fitzsimmons et al. ${ }^{17}$ & $\mathrm{SCO}$ & $49(80 \%)$ & Community & $\begin{array}{l}\text { 18-65 years old people, in precontemplation, } \\
\text { contemplation or preparation based in } \\
\text { transtheoretic model of behaviour change }\end{array}$ \\
\hline Keyserling et al. ${ }^{18}$ & USA & $53(100 \%)$ & $\begin{array}{c}\text { Community / Community Health } \\
\text { Centre }\end{array}$ & 40-64 years old low-income woman \\
\hline Koniak-Griffin et al. ${ }^{19}$ & USA & $45(100 \%)$ & $\begin{array}{c}\text { Community / Community Health } \\
\text { Centre }\end{array}$ & $\begin{array}{l}\text { Low-income overweight Latin-based woman } \\
\text { with 35-64 years old }\end{array}$ \\
\hline McMurdo et al. ${ }^{20}$ & $\mathrm{SCO}$ & $77(100 \%)$ & Primary Health Centres & $\geq 70$ years old physically inactive people \\
\hline Opdenacker et al..$^{21}$ & BEL & $67(52 \%)$ & Community & $\geq 60$ years old physically inactive people \\
\hline Schulz et al. ${ }^{22}$ & USA & 47 (nd) & $\begin{array}{l}\text { Community / Community } \\
\text { Associations }\end{array}$ & $\begin{array}{l}>18 \text { years old Latin-based or African American } \\
\text { people }\end{array}$ \\
\hline Warner et al. ${ }^{23}$ & GER & $70(75 \%)$ & Community & $\geq 64$ years old people \\
\hline Wilbur et al. ${ }^{24}$ & USA & $53(100 \%)$ & Community & $\begin{array}{c}\text { 40-65 years old physically inactive African } \\
\text { American woman }\end{array}$ \\
\hline
\end{tabular}

$\mathrm{BEL}=$ Belgium; GER = Germany; $\mathrm{nd}=$ not described; $\mathrm{SCO}=$ Scotland; USA = United States of America 
Table 2 - Intervention characteristics and physical activity assessment $(\mathrm{n}=9)$

\begin{tabular}{|c|c|c|c|c|c|}
\hline \multirow{2}{*}{ Reference } & \multicolumn{2}{|c|}{ Analysed no. (per group) } & \multirow{2}{*}{$\begin{array}{l}\text { Intervention length; } \\
\text { Implementers of the } \\
\text { intervention }\end{array}$} & \multirow{2}{*}{ Intervention } & \multirow{2}{*}{$\begin{array}{l}\text { Tool used for physical activity } \\
\text { assessment }\end{array}$} \\
\hline & INT & $\mathrm{CON}$ & & & \\
\hline Castro et al. ${ }^{16}$ & $20^{(\mathrm{a})}$ & 10 & $\begin{array}{l}12 \text { months; Health Specialists } \\
\text { and Physically Active } \\
\text { Voluntaries }\end{array}$ & $\begin{array}{l}\text { Educational content offered through } \\
14 \text { telephone calls, which could be done } \\
\text { either by a specialist or by a previously } \\
\text { trained volunteer. Based on Cognitive } \\
\text { Social Theory. }\end{array}$ & Accelerometer MTI Actigraph \\
\hline Fitzsimmons et al., ${ }^{17}$ & $39^{(\mathrm{b})}$ & 40 & 12 months; Health Specialists & $\begin{array}{l}\text { Receipt of pedometer and permanent } \\
\text { individual counselling (face-to-face and } \\
\text { via telephone). Members of the Control } \\
\text { group also received pedometers. }\end{array}$ & Pedometer Omron HJ-109E \\
\hline Keyserling et al. ${ }^{18}$ & $106^{(\mathrm{c})}$ & 106 & $\begin{array}{l}12 \text { months; Community } \\
\text { Health Workers }\end{array}$ & $\begin{array}{l}\text { Intervention divided into two } \\
\text { phases of six months (intensive } \\
\text { and maintenance). Were developed } \\
\text { Individual counselling activities, group } \\
\text { sessions, mailing and telephone calls. } \\
\text { The Control group received a pamphlet } \\
\text { about physical activity and healthy } \\
\text { eating. }\end{array}$ & Accelerometer Actigraph \\
\hline Koniak-Griffin et al. ${ }^{19}$ & 98 & 95 & $\begin{array}{l}6 \text { months; Community Health } \\
\text { Workers }\end{array}$ & $\begin{array}{l}\text { Eight educational meetings (classes), } \\
\text { home visits and follow-up by telephone } \\
\text { calls were done. The Control group } \\
\text { received training in disease prevention, } \\
\text { environmental disasters and home } \\
\text { safety (children and the elderly). }\end{array}$ & $\begin{array}{l}\text { Accelerometer Kenz } \\
\text { Lifecorder Plus }\end{array}$ \\
\hline McMurdo et al. ${ }^{20}$ & $53^{(\mathrm{d})}$ & 66 & 6 months; Research Team & $\begin{array}{l}\text { Educational meetings, counselling, } \\
\text { educational pamphlet delivery and } \\
\text { telephone monitoring were done. }\end{array}$ & $\begin{array}{l}\text { Accelerometer RT3 Triaxial } \\
\text { Research Tracker }\end{array}$ \\
\hline Opdenacker et al. ${ }^{21}$ & $40^{(\mathrm{e})}$ & 46 & 11 months; Health Specialists & $\begin{array}{l}\text { Individual follow-up (that generated } \\
\text { a physical activity adapted program, } \\
\text { involving resistance, strength, and } \\
\text { flexibility activities). Counselling with } \\
\text { Psychologists. Were also done group } \\
\text { activities and monitoring by telephone } \\
\text { calls. Based on Cognitive Social Theory. }\end{array}$ & $\begin{array}{l}\text { Accelerometer RT3 Tri-axial } \\
\text { Research Tracker; Pedometer } \\
\text { Yamax Digiwalker }\end{array}$ \\
\hline Schulz et al. ${ }^{22}$ & 388 & & $\begin{array}{l}8 \text { months; Community Health } \\
\text { Workers }\end{array}$ & $\begin{array}{l}\text { Three weekly walking activities } \\
\text { (between } 45-90 \text { minutes). The Control } \\
\text { group received intervention from the } \\
\text { eighth week after the baseline. }\end{array}$ & Pedometer Omron JH 112 \\
\hline Warner et al. ${ }^{23}$ & $84^{(\mathrm{f})}$ & $67^{(\mathrm{g})}$ & $\begin{array}{l}14 \text { months; Psychologists with } \\
\text { Ph.D. }\end{array}$ & $\begin{array}{l}\text { Counselling practices and education- } \\
\text { based meetings. }\end{array}$ & Accelerometer Geneactiv \\
\hline Wilbur et al. ${ }^{24}$ & $62^{(\mathrm{h})}$ & 52 & 12 months; Nursers & $\begin{array}{l}\text { Six group meetings, Individual } \\
\text { telephone calls. Based on Cognitive } \\
\text { Social Theory. }\end{array}$ & Accelerometer \\
\hline
\end{tabular}

$\mathrm{a}=$ Accelerometer-based analyses were directed for a sub-sample of 30 people (20 from two intervention groups and 10 from the control group); (b) = Pedometer-based walking programme plus physical activity consultations; (c) = Enhanced Intervention group; (d) = Behavior change intervention group; $(\mathrm{e})=$ Lifestyle intervention group; $(\mathrm{f})$ = Intervention group with views-on-ageing component; (g) = Passive control group; $(\mathrm{h})=$ Group meetings plus personal calls group.

\section{Discussion}

The aim of this study was to evaluate the effects of community-based RCT on PA levels in adults, considering the evidence from studies using objective methods to assess PA. Our systematic review found positive results in four interventions designed to increase the number of steps per day ${ }^{17,19,21,22}$ and in two interventions designed to increasing moderate and vigorous PA levels ${ }^{16,21}$.
Regarding the operational aspects of the interventions, with the exception of a strategy based on three-times a week walking sessions ${ }^{22}$, all the included interventions were based on educational activities, involving practices such as individual and group counselling, home visits and telephone calls. Our findings corroborate the evidence of a previous review, where it was pointed out that multicomponent interventions, based on educational activities, are 


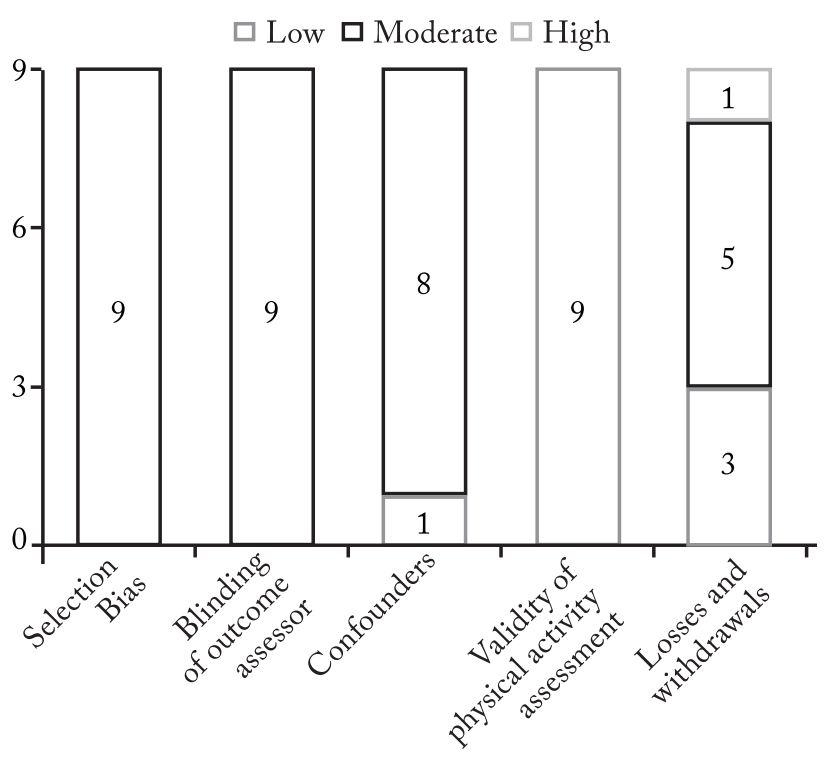

Figure 2 - Risk of Bias of included studies $(n=9)$

Table 3 - Synthesis of results $(n=9)$

\begin{tabular}{|c|c|}
\hline Reference & Indicator: Number of steps per day \\
\hline Fitzsimmons et al. ${ }^{17}$ & $\begin{array}{l}\text { A significant main effect of time was found } \\
\text { for step-counts but there was no significant } \\
\text { interaction effect }(p<0.001) \text {. Post-hoc tests } \\
\text { showed significant increases in steps/day between: } \\
\text { pre-intervention and } 48 \text { weeks }(p<0.001) \text {. }\end{array}$ \\
\hline Koniak-Griffin et al. ${ }^{19}$ & $\begin{array}{l}\text { The groups differed significantly (controlling } \\
\text { for age) in their change from baseline to nine } \\
\text { months }(p=0.04) \text {. }\end{array}$ \\
\hline Opdenacker et al. ${ }^{21}$ & $\begin{array}{l}\text { For the Intervention group the increase from } \\
\text { pretest to post-test was significantly larger than } \\
\text { the Control group with respect to daily steps }\end{array}$ \\
\hline Schulz et al. ${ }^{22}$ & $\begin{array}{l}\text { Participants in the intervention group increased } \\
\text { steps significantly more during the initial } \\
\text { eight-week intervention period, compared to the } \\
\text { control group }(p=0.000) \text {. }\end{array}$ \\
\hline Wilbur et al. ${ }^{24}$ & $\begin{array}{l}\text { The overall condition by-time interaction effect } \\
\text { was nonsignificant indicating an absence of } \\
\text { differential rates of change over time across the } \\
\text { groups }(p=0.135) \text {. }\end{array}$ \\
\hline Reference & $\begin{array}{l}\text { Indicator: Levels of moderate and vigorous } \\
\text { physical activity }\end{array}$ \\
\hline Castro et al. ${ }^{16(a)}$ & $\begin{array}{l}\text { The physical activity groups differed significantly } \\
\text { from the control group: } 22.4 \text { minutes per hour } \\
\text { versus } 5.7 \text { minutes per hour ( } \mathrm{p}=0.007 \text { ). }\end{array}$ \\
\hline Keyserling et al. ${ }^{18}$ & $\begin{array}{l}\text { The relative differences between groups were not } \\
\text { statistically significant (multivariate model, for } \\
\text { moderate PA at six and } 12 \text { months) }(\mathrm{p}=0.12) \text {. }\end{array}$ \\
\hline McMurdo et al. ${ }^{20}$ & $\begin{array}{l}\text { After adjustment for baseline differences, } \\
\text { accelerometry counts increased significantly more } \\
\text { in the Intervention group at three months than } \\
\text { in the Control group }(\mathrm{p}=0.002) \text {. By six months, } \\
\text { accelerometry counts in both intervention } \\
\text { groups had fallen to levels that were no longer } \\
\text { statistically significantly different from baseline. }\end{array}$ \\
\hline Opdenacker et al. ${ }^{21}$ & $\begin{array}{l}\text { For the lifestyle group the increase from } \\
\text { pretest to post-test was significantly larger } \\
\text { than the control group with respect to active } \\
\text { transportation and total physical activity }\end{array}$ \\
\hline Warner et al. ${ }^{23}$ & $\begin{array}{l}\text { Neither physical activity measure increased in the } \\
\text { Intervention group as compared to the Control } \\
\text { group at any point in time. }\end{array}$ \\
\hline
\end{tabular}

effective in promoting physical activity in populations of low socioeconomic status ${ }^{25}$. Also, education-based strategies show promising results in promising results in increasing PA levels and are well recommended ${ }^{26}$.

On the other hand, it is noteworthy pointing out that in many cases, only the educational practice is insufficient to change certain behaviours ${ }^{27}$, which requires, in this sense, greater approximation of professionals and multisectoral efforts for the discussion, planning and implementation of community-based strategies for PA promotion ${ }^{28}$. In addition, strategies also could focus on the other important individual changes, such as self-efficacy, empowerment and reduction of perceived barriers for $\mathrm{PA}$.

On the practice of counselling, the present synthesis reinforces the evidence of two previous syntheses ${ }^{29,30}$ and, as in the study of Breckon et al. ${ }^{31}$ warns of the need for further efforts about its development and reporting, in theoretical bases, description and modes of operation. We highlight the importance of counselling practices in the extended routine of primary health care, which can also predict the involvement of different health specialists in the activities, who can also apply questionnaires and PA recalls, in order to recognize and discuss the main barriers to the practice of PA and development of educational activities ${ }^{32}$.

Telephone support is presented in the literature as an important alternative, not only in relation to PA, but also for healthy eating ${ }^{33,34}$. In order to add to the counselling practices (individual or in group), the present synthesis suggests that the introduction of telephone calls can also be a potential strategy for increasing PA levels in the community setting.

Most of the interventions that presented significant PA levels were implemented during 11 and 12 months. Although other positive effects have been observed in shorter interventions (six and eight months), we suggest that the actions provided for in the research protocols be maintained, favouring the maintenance of the behaviour ${ }^{35}$.

Health specialists and CHW have implemented most of the included interventions. Considering their continuous insertion in the communities, CHW represents important actors in primary health care actions and corroborating previous evidence ${ }^{36}$, we suggest that the CHW could receive more extensive training and play broader roles in PA promotion actions in the communities.

Most of the included interventions targeted specific samples, such as women, populations with ages over 
45 years, lower socioeconomic level populations and physically inactive persons. Although all the included studies were conducted in high-income countries, according to the World Bank classification, a considerable part of the evidence supporting this synthesis has been found in populations living in different situations of vulnerability.

Since the socioeconomic issue is determinant for the PA practice, particularly in leisure time ${ }^{37,38}$, we highlight the need for public policies and community strategies that have the purpose of reducing inequities, increasing access and possibilities for PA. Recognizing the importance of the socioeconomic factors, we highlight the need for public policies and communitybased strategies aimed at reducing inequity, increasing access and possibilities for PA.

The decision to only include RCT with over sixmonth interventions and PA assessed by objective methods were to improve comparability between them and to provide evidence that could help future studies, recognizing the high heterogeneity indicated by a previous review ${ }^{11}$. Although the literature points to a minimum period of six months for behavioural changes ${ }^{10}$, many interventions were implemented in shorter periods of time than recommended, leaving questions as to whether their positive results were due to the acute effects of these interventions.

Also, we recognize that although objective methods produce measures that are less overestimated than questionnaires, as has already been pointed out, advances are required for motion sensors to become the most complete for PA assessment ${ }^{39,40}$. Thus, it should be pointed out that six studies also used questionnaires to PA assessment, as a support tool to identify type(s) of PA performed, settings and intensity of the activities ${ }^{16-18,21,23,24}$.

As main limitations of this review, we highlight that the synthesis does not allow generalizations. Similar to a previous study ${ }^{11}$, high heterogeneity among populations, strategies applied in the interventions and methods for PA evaluation were observed, suggesting that all these specificities need to be taken into account in formulation of future community-based strategies for strategies for increasing PA levels.

In conclusion, most of the studies included showed the potential of community-based interventions to increase the number of steps per day. It is important that future studies discuss operational strategies of interventions, such as counselling and home visits.

\section{Conflict of interest}

The authors declare no conflict of interest.

\section{Author's contributions}

Guerra PH, conception of central idea of the study, elaboration of systematic searches, assessment of titles/abstracts, full texts and risk of bias, development of the synthesis, analysis of the results and writing of the text; Ribeiro EHC, elaboration of systematic searches, assessment of titles/abstracts, full texts and risk of bias, analysis of results and text review; Lima TR, risk of bias assessment, analysis of results and text review; Andrade DR, analysis of results and text review and Loch MR, analysis of results and text review.

\section{Funding}

Conselho Nacional de Desenvolvimento Científico e Tecnológico, process no: 449975/2014-2.

\section{References}

1. Hackshaw-McGeagh LE, Perry RE, Leach VA, Qandil S, Jeffreys M, Martin RM, et al. A systematic review of dietary, nutritional, and physical activity interventions for the prevention of prostate cancer progression and mortality. Cancer Causes Control. 2015;26(11):1521-50.

2. Schmid D, Behrens G, Keimling M, Jochem C, Ricci C, Leitzmann M. A systematic review and meta-analysis of physical activity and endometrial cancer risk. Eur J Epidemiol. 2015;30(5):397-412.

3. Alothman S, Yahya A, Rucker J, Kluding PM. Effectiveness of interventions for promoting objectively measured physical activity of adults with type 2 diabetes: a systematic review. J Phys Act Health. 2017;14(5):408-15.

4. Cradock KA, ÓLaighin G, Finucane FM, Gainforth HL, Quinlan LR, Ginis KA. Behaviour change techniques targeting both diet and physical activity in type 2 diabetes: A systematic review and meta-analysis. Int J Behav Nutr Phys Act. 2017;14(1):18.

5. Lee IM, Shiroma EJ, Lobelo F, Puska P, Blair SN, Katzmarzyk $\mathrm{PT}$, et al. Effect of physical inactivity on major noncommunicable diseases worldwide: an analysis of burden of disease and life expectancy. Lancet. 2012;380(9838):219-29.

6. Hallal PC, Andersen LB, Bull FC, Guthold R, Haskell W, Ekelund U, et al. Global physical activity levels: surveillance progress, pitfalls, and prospects. Lancet. 2012;380(9838):247-57.

7. Eisenberg Y, Vanderbom KA, Vasudevan V. Does the built environment moderate the relationship between having a disability and lower levels of physical activity? A systematic review. Prev Med. 2017;95S:S75-S84.

8. Davies MJ, Gray LJ, Troughton J, Gray A, Tuomilehto J, Farooqi A, et al. A community based primary prevention programme for type 2 diabetes integrating identification and lifestyle intervention for prevention: the Let's Prevent Diabetes cluster randomised controlled trial. Prev Med. 2016;84:48-56.

9. Kidd SA, Davidson L, McKenzie K. Common factors in community mental health intervention: a scoping review. Community Ment Health J. 2017;53(6):627-37. 
10. Skevington SM, Sovetkina EC, Gillison FB. A systematic review to quantitatively evaluate 'stepping stones': a participatory community-based hiv/aids prevention intervention. AIDS Behav. 2013;17(3):1025-39.

11. Baker PR, Francis DP, Soares J, Weightman AL, Foster C. Community wide interventions for increasing physical activity. Cochrane Database Syst Rev. 2015;1:CD008366.

12. Lee PH, Macfarlane DJ, Lam TH, Stewart SM. Validity of the international physical activity questionnaire short form (ipaq-sf): a systematic review. Int J Behav Nutr Phys Act. 2011;8:115.

13. Adamo KB, Prince SA, Tricco AC, Connor-Gorber S, Tremblay M. A comparison of indirect versus direct measures for assessing physical activity in the pediatric population: a systematic review. Int J Pediatr Obes. 2009;4(1):2-27.

14. Guerra PH, Cuce Nobre MR, Cardoso da Silveira JA, Aguiar Carrazedo Taddei JA. School-based physical activity and nutritional education interventions on body mass index: A meta-analysis of randomised community trials - Project PANE. Prev Med. 2014;61:81-9.

15. Thomas BH, Ciliska D, Dobbins M, Micucci S. A process for systematically reviewing the literature: providing the research evidence for public health nursing interventions. Worldviews Evid Based Nurs. 2004;1(3):176-84.

16. Castro CM, Pruitt LA, Buman MP, King AC. Physical activity program delivery by professionals versus volunteers: the team randomized trial. Health Psychol. 2011;30(3):285-94.

17. Fitzsimons CF, Baker G, Gray SR, Nimmo MA, Mutrie N, (SPARColl) SPARC. Does physical activity counselling enhance the effects of a pedometer-based intervention over the long-term: 12-month findings from the walking for wellbeing in the west study. BMC Public Health. 2012;12:206.

18. Keyserling TC, Samuel Hodge CD, Jilcott SB, Johnston LF, Garcia BA, Gizlice Z, et al. Randomized trial of a clinic-based, community-supported, lifestyle intervention to improve physical activity and diet: the north carolina enhanced wisewoman project. Prev Med. 2008;46(6):499-510.

19. Koniak-Griffin D, Brecht ML, Takayanagi S, Villegas J, Melendrez M, Balcázar H. A community health worker-led lifestyle behavior intervention for latina (hispanic) women: feasibility and outcomes of a randomized controlled trial. Int J Nurs Stud. 2015;52(1):75-87.

20. McMurdo ME1, Sugden J, Argo I, Boyle P, Johnston DW, Sniehotta FF, et al. Do pedometers increase physical activity in sedentary older women? A randomized controlled trial. J Am Geriatr Soc. 2010;58(11):2099-106.

21. Opdenacker J, Boen F, Coorevits N, Delecluse C. Effectiveness of a lifestyle intervention and a structured exercise intervention in older adults. Prev Med. 2008;46(6):518-24.

22. Schulz AJ, Israel BA, Mentz GB, Bernal C, Caver D, DeMajo $\mathrm{R}$, et al. Effectiveness of a walking group intervention to promote physical activity and cardiovascular health in predominantly non-hispanic black and hispanic urban neighborhoods: findings from the walk your heart to health intervention. Health Educ Behav. 2015;42(3):380-92.

23. Warner LM, Wolff JK, Ziegelmann JP, Schwarzer R, Wurm S. Revisiting self-regulatory techniques to promote physical activity in older adults: null-findings from a randomised controlled trial. Psychol Health. 2016;31(10):1145-65.
24. Wilbur J, Miller AM, Fogg L, McDevitt J, Castro CM, Schoeny ME, et al. Randomized clinical trial of the women's lifestyle physical activity program for african-american women: 24- and 48-Week Outcomes. Am J Health Promot. 2016;30(5):335-45.

25. Cleland CL, Tully MA, Kee F, Cupples ME. The effectiveness of physical activity interventions in socio-economically disadvantaged communities: a systematic review. Prev Med. 2012;54(6):371-80.

26. Heath GW1, Parra DC, Sarmiento OL, Andersen LB, Owen N, Goenka S, et al. Evidence-based physical activity intervention: lessons from around the globe. Lancet. 2012;380:272-81.

27. Marteau TM. Changing minds about changing behaviour. Lancet. 2018;391(10116):116-7.

28. Reis RS, Salvo D, Ogilvie D, Lambert EV, Goenka S, Brownson RC, et al. Scaling up physical activity interventions worldwide: stepping up to larger and smarter approaches to get people moving. Lancet. 2016;388(10051):1337-48.

29. Patnode CD, Evans CV, Senger CA, Redmond N, Lin JS. Behavioral counseling to promote a healthful diet and physical activity for cardiovascular disease prevention in adults without known cardiovascular disease risk factors: updated evidence report and systematic review for the us preventive services task force. JAMA. 2017;318(2):175-93.

30. Lin JS, O'Connor E, Whitlock EP, Beil TL. Behavioral counseling to promote physical activity and a healthful diet to prevent cardiovascular disease in adults: a systematic review for the u.s. preventive services task force. Ann Intern Med. 2010;153(11):736-50.

31. Breckon JD, Johnston LH, Hutchison A. Physical activity counseling content and competency: a systematic review. J Phys Act Health. 2008;5(3):398-417.

32. Berra K, Rippe J, Manson JE. Making physical activity counseling a priority in clinical practice: the time for action is now. JAMA. 2015;314(24):2617-8.

33. Goode AD, Reeves MM, Eakin EG. Telephone-delivered interventions for physical activity and dietary behavior change: an updated systematic review. Am J Prev Med. 2012;42(1):81-8.

34. Eakin EG, Lawler SP, Vandelanotte C, Owen N. Telephone interventions for physical activity and dietary behavior change: a systematic review. Am J Prev Med.2007;32(5):41934.

35. Greaves CJ, Sheppard KE, Abraham C, Hardeman W, Roden M, Evans PH, et al. Systematic review of reviews of intervention components associated with increased effectiveness in dietary and physical activity interventions. BMC Public Health. 2011;11:119.

36. Costa EF, Guerra PH, dos Santos TI, Florindo AA. Systematic review of physical activity promotion by community health workers. Prev Med. 2015;81:114-21.

37. O’Donoghue G, Kennedy A, Puggina A, Aleksovska K, Buck C, Burns C, et al. Socio-economic determinants of physical activity across the life course: a "determinants of diet and physical activity" (dedipac) umbrella literature review. PLoS One. 2018;13(1):e0190737.

38. Tovar M, Walker JL, Rew L. Factors associated with physical activity in latina women: a systematic review. West J Nurs Res. 2018;40(2):270-97.

39. Lee IM, Shiroma EJ. Using accelerometers to measure physical activity in large-scale epidemiological studies: issues and challenges. Br J Sports Med. 2014;48(3):197-201. 
40. Dowd KP, Szeklicki R, Minetto MA, Murphy MH, Polito A, Ghigo E, et al. A systematic literature review of reviews

Received: $23 / 03 / 2020$ on techniques for physical activity measurement in adults: a DEDIPAC study. Int J Behav Nutr Phys Act. 2018;15(1):15.

\section{Quote this article as:}

Guerra PH, Ribeiro EHC, Rodrigues TL, Andrade DR, Loch MR. Effects of community-based interventions on physical activity promotion: systematic review. Rev Bras Ativ Fis Saúde. 2020;25:e0130. DOI: 10.12820/rbafs.25e0130 